\title{
From sewage sludge ash to calcium phosphate fertilizers
}

\author{
Katarzyna Gorazda*, Zygmunt Kowalski, Zbigniew Wzorek \\ Institute of Chemistry and Inorganic Technology, Cracow University of Technology, ul. Warszawska 24, 31-155 Kraków, Poland, \\ "Corresponding authors: gorazda@chemia.pk.edu.pl
}

\begin{abstract}
Our work presents the results of the research on the utilization of ashes after sewage sludge combustion comprising phosphorus recovery in the form of useful products. The investigations were divided into three parts: selecting the combustion parameters of sewage sludge, examining ash leaching with mineral acids (nitric and phosphoric) to high phosphorus selectivity assuring a low content of iron and heavy metals in the extracted solutions and precipitation of $\mathrm{CaHPO}_{4} \cdot 2 \mathrm{H}_{2} \mathrm{O}$. Suitable temperature of a sewage sludge combustion enables selective extraction of phosphorus compounds from ash because of hematite phase forming, insoluble in mineral acids. The extracts from phosphoric acid leaching, where the extraction of phosphorus compounds was $96.1 \%$, have very good properties for its further use as the initial solution for $\mathrm{CaHPO}_{4} \cdot 2 \mathrm{H}_{2} \mathrm{O}$ with $6 \%$ lime milk. The obtained product is characterized by high purity and phosphorus availability compatible even with the feed phosphate standard.
\end{abstract}

Keywords: phosphorus recovery, sewage sludge, sewage sludge combustion, ash extraction, fertilizers production, waste

\section{INTRODUCTION}

Meeting the human demands on phosphorus products, more than $80 \%$ of them can be met in phosphorus fertilizers and $12 \%$ in detergents and animal feed. Presently, over 30 countries exploit natural phosphorus deposits, mostly of a sedimentary nature. $65 \%$ of the world=raw material production in 2009 was covered by China, United States, Marocco and Western Sahara. $66 \%$ of the world phosphate rock reserves are present in those countries ${ }^{1,2,3}$. According to the forecasts, the world phosphorites and apatites reserves will become exhausted during the next $60-130$ years ${ }^{3,4}$. On the other hand, increased phosphorus contents at superficial waters contribute to its contamination and eutrophication ${ }^{3,4,5}$. In order to minimize the environmental impact, phosphorus must be removed from the industrial, farming and municipal sewage during treatment processes. Meeting the requirements for the quality of purified sewage involves applying high-effective biological and chemical treatment methods, therefore we generate a sewage sludge - a waste containing phosphorus compounds concentrated into the cellular matter or as an insoluble phosphates - potential substitute of a natural phosphate rock.

A sewage sludge, with respect to the quantity, is a relatively small part of all wastes generated at municipal and economic sector, but due to their environmental impact the importance of that group is significant. Due to more restrictive regulations applied to the conditions of sewage sludge utilisation and phosphorus ore deposits depletion, investigations related to phosphorus recovery from sewage sludge have become more relevant ${ }^{6-9}$. Thermal processing of a sewage sludge, where phosphorus is removed by chemical precipitation, is proposed to be a preferable method for their utilisation and obtaining the product in the form of ash could be potentially used as a substitute of natural ore.

The sewage sludge processing technologies are still being developed ${ }^{10-12}$. The best known and advanced is Combi/Krepro ${ }^{T M}$ process, being the combination of the earlier systems Combi and Kemira/Alfa Laval ${ }^{8,13,14}$. The de- hydrated sewage sludge is hydrolyzed at the temperature of $150^{\circ} \mathrm{C}$ in order to eliminate an organic material and leach the phosphorus and metal compounds. Sulphuric acid is used for hydrolysis and at the final stage iron (III) phosphate in $75 \%$ is recovered. A concentrated fraction of sludge can be used as a biofuel ${ }^{13}$. The pilot installation has worked since 1995 at the Sewage Treatment Plant at Helsingborg in Sweden. The Bio-Con process makes use of sewage sludge combustion in a grate furnace at the temperature of $850^{\circ} \mathrm{C}$ within 2 seconds and the obtained ash is processed with the use of sulphuric acid ${ }^{8,13}$. The application of an ionic exchange process allowed to eliminate the impurities and phosphorus recovery in the form of phosphoric acid. The Japanese EBPR process proposes intensive ash washing with demineralised water at $53^{\circ} \mathrm{C}$ or sulphuric acid ${ }^{6,13}$. A new technology of melted calcium-magnesium phosphate production from ash after sewage sludge combustion was also developed ${ }^{15,16}$. The ash with a relevant calcium and magnesium addition was melted at the temperature of $1350-1500^{\circ} \mathrm{C}$. The obtained product meets the requirements of Japanese fertilizer standards. In the year 2000 the technology of white phosphorus production from sewage sludge was patented ${ }^{17}$. The process is performed at $1000-1250^{\circ} \mathrm{C}$ in oxygen-free conditions. The sewage sludge after earlier carbonization at the temperature of $400-700^{\circ} \mathrm{C}$ or mixture of ash and coal was used as a furnace charge.

The pathways to recover phosphorus from a sewage sludge via thermal treatment is the main goal of the $S U$ $S A N$ project (Sustainable and Safe Re-Use of Municipal Sewage Sludge for Nutrient Recovery), funded under the EU 6th Framework R\&D Programme. Treating the sewage sludge ash through a thermal process $\left(850-1100^{\circ} \mathrm{C}\right)$ with a chlorine addition $\left(\mathrm{MgCl}_{2}, \mathrm{CaCl}_{2}, \mathrm{KCl}\right)$ in order to remove heavy metals and transform phosphorus into an available mineral form was proposed ${ }^{18-22}$. On the other hand, leaching processes of sewage sludge ash with mineral acids are strongly developed. At the proposed solutions sewage sludge ash is leached with sulfuric acid, the solution is then purified on ion exchange columns to produce technical grade phosphoric acid. As a sec- 
ond product powdery fertilizers in the form of calcium phosphate can be also manufactured ${ }^{23-24}$.

The research results presented below use a three-stage method: combustion of sewage sludge, then the extraction of received ash with nitric or phosphoric acid and precipitation of $\mathrm{CaHPO}_{4} \cdot 2 \mathrm{H}_{2} \mathrm{O}$ with $6 \%$ lime milk ${ }^{25-29}$.

\section{EXPERIMENTAL}

Studies on the sewage sludge incineration were carried out with the mixture of biological sludge (excessive and preliminary) from the sewage treatment plant Kujawy at Kraków (Poland). That unit treats approximately $54000 \mathrm{~m}^{3}$ of the sewage per day from 250000 residents (equivalent number of residents $=310000$ ). From the raw sewage, which contains $7 \mathrm{mg}$ total $\mathrm{P} / \mathrm{dm}^{3}$, mechanical residue, suspended solid matter, substances cause BOD, nitrogen and phosphorus compounds are removed. Mostly chemical precipitation is used for phosphorus removal. $100 \mathrm{~g}$ of the precipitation agent -PIX $(40.5 \%$ solution of $\left.\mathrm{Fe}_{2}\left(\mathrm{SO}_{4}\right)_{3}\right)$ is used per $1 \mathrm{~m}^{3}$ of sewage. After the treatment processes phosphorus concentration obtained in the sewage obtain is $1.1 \mathrm{mg} / \mathrm{dm}^{3}$. Additionally sludge is treated by methane fermentation, gravitationally concentrated than disposed in quantity $\sim 55 \mathrm{Mg} /$ day $\left(70 \% \mathrm{H}_{2} \mathrm{O}\right)$.

The chemical characteristic of sewage sludge ash calcined at the temperature of $950^{\circ} \mathrm{C}$ for $3 \mathrm{~h}$ was: $22.86 \%$ $\mathrm{PO}_{4}^{-3}, 16.8 \% \mathrm{Fe}, 11.8 \% \mathrm{Ca}, 1,12 \% \mathrm{Mg}, 0.54 \% \mathrm{Zn}$, $0.012 \% \mathrm{~Pb}, 0.054 \% \mathrm{Cu}, 0.017 \% \mathrm{Ni}, 0.070 \% \mathrm{Cr}, 0.0020 \%$ $\mathrm{Cd}, 0.005 \%$ Co. According to X-ray analysis the main phases of the obtained ash was $\mathrm{SiO}_{2}$, anhydrite, hematite and $\mathrm{Ca}_{9} \mathrm{Fe}\left(\mathrm{PO}_{4}\right)_{7}$.

\section{RESULTS AND DISCUSSION}

The conducted investigations, applied to influence sewage sludge combustion temperature on the obtained ash composition, reveal that phosphorus compounds recovery depends significantly on the parameters of thermal processing. In the instance when sewage treatment plant uses chemical precipitation for phosphorus removal in the form of iron phosphate, the sewage sludge, as well as the obtained ash, contain unwanted iron ions, which have an unfavourable impact on phosphorus availability.

It was found that the selective extraction of phosphorus compounds from ash calcined at $600-1000^{\circ} \mathrm{C}$ was possible because of the appearance of insoluble hematite phase $\left(\mathrm{Fe}_{2} \mathrm{O}_{3}\right)$. An increase of the sewage sludge incineration temperature resulted in iron bounding into hematite phase and as a consequence the concentration of iron extracted simultaneously with phosphorus into solution decreased (Fig. 1).

Further investigations were carried out with the purpose of the selection of the best conditions for phosphorus compounds extraction from ash after thermal processing of sewage sludge at $950^{\circ} \mathrm{C}$ with the use of nitric and also phosphoric acids. The main goal was the determination of the minimum amount of acid usage together with high phosphorus leaching efficiency and selectivity in relation to iron ions. The extractions trials were carried out with the concentration of nitric and phosphoric acid varied from 2.7 to $3.7 \mathrm{~mol} / \mathrm{dm}^{3}$ while the mass ratio of
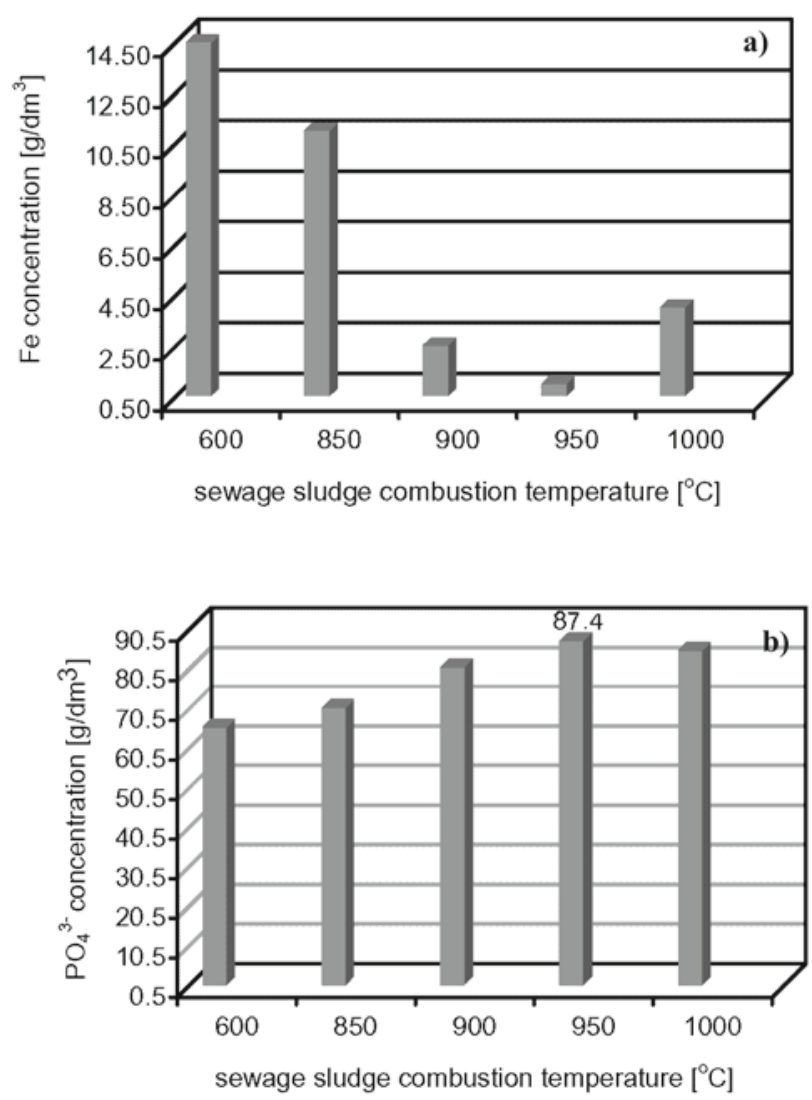

Figure 1. Influence of sewage sludge combustion temperature on $\mathrm{Fe}$ and $\mathrm{PO}_{4}^{3-}$ concentration in solutions after ash extraction with $3.68 \mathrm{~mol} / \mathrm{dm}^{3} \mathrm{HNO}_{3}$

the extracted ash to acid mixture were changed in the range of $0.5-0.7 \mathrm{~g} / \mathrm{g}$.

The increase of ash to acid mass ratio, decreases $\mathrm{PO}_{4}{ }^{3-}$ extraction degree $(\alpha)$ from $97.4 \%$ to $94 \%$ (nitric acid) and from 96.6 to $86.9 \%$ (phosphoric acid) but enlarges the capacity of the extraction process (n) from 0.25 to 0.45 mole $\mathrm{PO}_{4}{ }^{3-}$ leached from ash per mole of used nitric acid and from 0.25 to 0.35 mole $\mathrm{PO}_{4}{ }^{3-}$ leached from ash per mole of used phosphoric acid.

The initial increase of ash to phosphoric acid mass ratio from 0.33 to 0.41 results in solution saturation with extracted components, but further increase causes supersaturation of the solutions, which initiates a precipitation processes.

Over $97 \%(97.3-99.6 \%)$ of iron from ash is contained in the solid residue after the extraction process with nitric as well as phosphoric acid, which indicates the effectiveness of the preliminary stage of ash treatment.

Finally, in the case of nitric acid, application of $0.45 \mathrm{~g} / \mathrm{g}$ acid to ash mass ratio and acid concentration $2.71 \mathrm{~mol} / \mathrm{dm}^{3}$ was admitted as favourable. Using these conditions results in $94.89 \%$ of $\mathrm{PO}_{4}{ }^{3-}$ ions recovery and high extraction productivity $-0.42 \mathrm{~mol} \mathrm{PO}_{4}{ }^{3-} / \mathrm{mol} \mathrm{HNO}_{3}$.

In the case of phosphoric acid, application of $0.37 \mathrm{~g} / \mathrm{g}$ acid to ash mass ratio and acid concentration $2.68 \mathrm{~mol} / \mathrm{m}^{3}$ was admitted as favourable. Under those conditions $\mathrm{PO}_{4}{ }^{3-}$ extraction degree $(\alpha)$ reaches $96.1 \%$, and one mole of the used acid extracts 0.35 moles of phosphate ions with good mixing conditions. Moreover, phosphate compounds precipitation did not appear despite the high total phosphate ions concentrations in the solution near $347.5 \mathrm{~g} / \mathrm{dm}^{3}$. 
The extracts from phosphoric acid leaching have more advisable properties for its further use as the initial solution for the precipitation process of useful phosphate compounds (Table 1).

Table 1. Chemical constitution of extracts after ash leaching with $2.71 \mathrm{~mol} / \mathrm{dm}^{3} \mathrm{HNO}_{3}$ and $2.68 \mathrm{~mol} / \mathrm{dm}^{3} \mathrm{H}_{3} \mathrm{PO}_{4}$

\begin{tabular}{|l|c|c|}
\hline Content & \multicolumn{2}{|c|}{$\begin{array}{c}\text { Chemical constitution of extracts } \\
{\left[\mathrm{g} / \mathrm{dm}^{3}\right]}\end{array}$} \\
\hline $\begin{array}{l}\text { Ash to acid mass ratio } \\
\text { [g/g] }\end{array}$ & 0.37 & 0.45 \\
\hline Used acid & $\mathrm{H}_{3} \mathrm{PO}_{4}$ & $\mathrm{HNO}_{3}$ \\
\hline $\mathrm{Fe}$ & 1,65 & 1.85 \\
\hline $\mathrm{PO}_{4}{ }^{3-}$ & 347,5 & 103.9 \\
\hline $\mathrm{Ca}$ & 41.0 & 43.5 \\
\hline $\mathrm{Mg}$ & 4.13 & 4.60 \\
\hline $\mathrm{Zn}$ & 0.726 & 0.82 \\
\hline $\mathrm{Cu}$ & 0.109 & 0.113 \\
\hline $\mathrm{Ni}$ & 0.0052 & 0.0061 \\
\hline $\mathrm{Cr}$ & 0.074 & 0.0056 \\
\hline $\mathrm{Cd}$ & 0.0037 & 0.0022 \\
\hline $\mathrm{Co}$ & 0.0039 & 0.0023 \\
\hline $\mathrm{Pb}$ & 0.026 & 0.019 \\
\hline
\end{tabular}

The aim of the third part of the research was defining proper conditions for selective precipitation of phosphorus compounds in the form of $\mathrm{CaHPO}_{4} \cdot 2 \mathrm{H}_{2} \mathrm{O}$ from the extracts and analysing its physicochemical properties in terms of probable application. The experiments were carried out on the model solutions, in which the concentration of all the analysed ingredients were analogical as in the extracts after ash leaching with nitric and phosphoric acid under the most beneficial conditions. The product precipitation was carried out at $\mathrm{pH}=2.5 ; 3 ; 4$ and 7 , in each experimental series, with $6 \%$ lime milk.
Using the fuzzy logic method with assessment criteria specified in table 2 it was found that the best conditions for $\mathrm{CaHPO}_{4} \cdot 2 \mathrm{H}_{2} \mathrm{O}$ precipitation were obtained when the extracts after ash leaching with $2.68 \mathrm{~mol} / \mathrm{dm}^{3}$ phosphoric acid were used. The precipitation process should be conducted to complete solution neutralization $(\mathrm{pH}=7)$ with $6 \%$ lime milk. That process receive six acceptable grade and only one admissible grade (Table 3 ). The obtained product is characterized by high purity (Table 4) and phosphorus availability compatible with the feed phosphate standard. Only $\mathrm{Pb}$ content is insignificantly exceeded.

On the basis of the conducted research the flow sheet of phosphorus recovery from sewage sludge was proposed (Fig. 2).

Sewage sludge ( $70 \%$ of water content) is charged into the rotary furnace and calcined at temperature of $950^{\circ} \mathrm{C}$ within $3 \mathrm{~h}$. The obtained ash is than extracted with phosphoric acid $\left(2.68 \mathrm{~mol} / \mathrm{dm}^{3}\right.$ and ash to acid ratio $\sim 0.37 \mathrm{~g} / \mathrm{g}$ ) within 4 hours at reactor with a stirrer and cooling circulation. After filtration on the filter-press the solution is directed into precipitation process and the solid residue after rinsing is directed on the stockyard or further treatment (iron recovery).

At the crystallization point the lime milk is dosed into the reactor with a stirrer and $\mathrm{pH}$-measurement until complete neutralization $(\mathrm{pH}=7)$ is achieved. Then the mixture should be stirred for further $2 \mathrm{~h}$. After the filtration on the press-filters, the solid residue is rinsed and prepared for fertilizer purposes while the water with the filtrate is recycled into the process.

The obtained product $\mathrm{CaHPO}_{4} \cdot 2 \mathrm{H}_{2} \mathrm{O}-\mathrm{DCP}-$ dicalcium phosphate is one of the most popular feed phosphate and also fertilizer phosphate. The lowest possible fluorine, arsenic and heavy metals content as well as phosphorus availability are the crucial criteria of its usability.

Table 2. Assessment criteria for $\mathrm{CaHPO}_{4} \cdot 2 \mathrm{H}_{2} \mathrm{O}$ precipitation process

\begin{tabular}{|l|c|c|c|c|c|c|c|}
\hline \multirow{2}{*}{ Grades } & Process parameters & \multicolumn{5}{|c|}{ Product parameters } \\
\cline { 2 - 7 } & $\begin{array}{c}\text { Efficiency of } \mathrm{PO}_{4}^{3-} \\
\text { removal from solution } \\
{[\%]}\end{array}$ & $\begin{array}{c}\text { Total } \\
\text { phosphorus } \\
{\left[\% \mathrm{P}_{2} \mathrm{O}_{5}\right]}\end{array}$ & $\begin{array}{c}\text { Phosphorus } \\
\text { soluble in 0.4\% } \\
\mathrm{HCl} \\
{\left[\% \mathrm{P}_{2} \mathrm{O}_{5}\right]}\end{array}$ & $\begin{array}{c}\text { Phosphorus soluble in } \\
2 \% \text { citric acid } \\
{\left[\% \mathrm{P}_{2} \mathrm{O}_{5}\right]}\end{array}$ & $\begin{array}{c}\mathrm{Ca} \\
{[\%]}\end{array}$ & $\begin{array}{c}\mathrm{Pb} \\
{[\%]}\end{array}$ & $\begin{array}{c}\mathrm{Cd} \\
{[\%]}\end{array}$ \\
\hline $\begin{array}{l}\text { acceptable } \\
,+"\end{array}$ & $>90 \%$ & $>41.0$ & $>33.2$ & $>99.0$ & $23.3-30$ & $<0.0030$ & $<0.0010$ \\
\hline $\begin{array}{l}\text { admissible } \\
,+/-"\end{array}$ & $80 \%-90 \%$ & $36.6-41.0$ & 33.2 & $98.0-99.0$ & $21-23.3$ & $0.003-0.005$ & 0.0010 \\
\hline $\begin{array}{l}\text { unacceptable } \\
,-,\end{array}$ & $<80 \%$ & $<36.6$ & $<33.2$ & $<98.0$ & $<21$ & $>0.005$ & $>0.0010$ \\
\hline
\end{tabular}

Table 3. The assessment of conducted experiments of $\mathrm{CaHPO}_{4} \cdot 2 \mathrm{H}_{2} \mathrm{O}$ precipitation

\begin{tabular}{|c|c|c|c|c|c|c|c|}
\hline \multirow[b]{2}{*}{ Experiment } & \multirow{2}{*}{$\begin{array}{c}\text { Process parameters } \\
\text { Efficiency of } \mathrm{PO}_{4}{ }^{3-} \\
\text { removal from solution } \\
{[\%]}\end{array}$} & \multicolumn{6}{|c|}{ Product parameters } \\
\hline & & $\begin{array}{c}\text { Total } \\
\text { phosphorus } \\
{\left[\% \mathrm{P}_{2} \mathrm{O}_{5}\right]}\end{array}$ & $\begin{array}{c}\text { Phosphorus } \\
\text { soluble in } 0,4 \% \\
\mathrm{HCl} \\
{\left[\% \mathrm{P}_{2} \mathrm{O}_{5}\right]}\end{array}$ & $\begin{array}{c}\text { Phosphorus soluble in } \\
2 \% \text { citric acid } \\
{\left[\% \mathrm{P}_{2} \mathrm{O}_{5}\right]}\end{array}$ & $\begin{array}{l}\mathrm{Ca} \\
{[\%]}\end{array}$ & $\begin{array}{l}\mathrm{Pb} \\
{[\%]}\end{array}$ & $\begin{array}{l}\mathrm{Cd} \\
{[\%]}\end{array}$ \\
\hline $\begin{array}{l}\text { Phosphoric acid } \\
\mathrm{pH}=4.06\end{array}$ & $+1-$ & + & + & $+/-$ & + & $+/-$ & + \\
\hline $\begin{array}{l}\text { Phosphoric acid } \\
\mathrm{pH}=7.04\end{array}$ & + & + & + & + & + & $+/-$ & + \\
\hline $\begin{array}{l}\text { Nitric acid } \\
\mathrm{pH}=4.08\end{array}$ & - & - & - & $+/-$ & - & - & + \\
\hline $\begin{array}{l}\text { Nitric acid } \\
\mathrm{pH}=7.32\end{array}$ & + & + & + & + & - & - & + \\
\hline
\end{tabular}


Table 4. Comparison of precipitants properties to standard requirements for feed phosphate

\begin{tabular}{|c|c|c|c|}
\hline \multirow[t]{2}{*}{ Characteristic } & $\begin{array}{c}\text { Extractant: } \\
\text { phosphoric acid }\end{array}$ & Extractant: nitric acid & \multirow[t]{2}{*}{ standard requirements } \\
\hline & $\mathrm{pH}=7.04$ & $\mathrm{pH}=7.32$ & \\
\hline Total phosphorus $\left[\% \mathrm{P}_{2} \mathrm{O}_{5}\right]$ & 41.23 & 41.21 & not more than 36.64 \\
\hline $\begin{array}{l}\text { Phosphorus soluble in } 0.4 \% \mathrm{HCl} \\
{\left[\% \mathrm{P}_{2} \mathrm{O}_{5}\right]}\end{array}$ & 40.86 & 39.22 & $\begin{array}{c}\text { not less than } \\
33.21 \\
\end{array}$ \\
\hline $\begin{array}{l}\text { Phosphorus soluble in } 2 \% \text { citric acid } \\
{\left[\% \mathrm{P}_{2} \mathrm{O}_{5}\right]}\end{array}$ & 40.99 & 40.87 & - \\
\hline $\mathrm{Ca}[\%]$ & 23.21 & 17.87 & $21-30$ \\
\hline $\mathrm{Pb}[\%]$ & 0.0046 & 0.00663 & $\begin{array}{c}\text { not more than } \\
0.0030 \\
\end{array}$ \\
\hline Cd [\%] & 0.00062 & 0.000663 & $\begin{array}{c}\text { not more than } \\
0.0010\end{array}$ \\
\hline
\end{tabular}

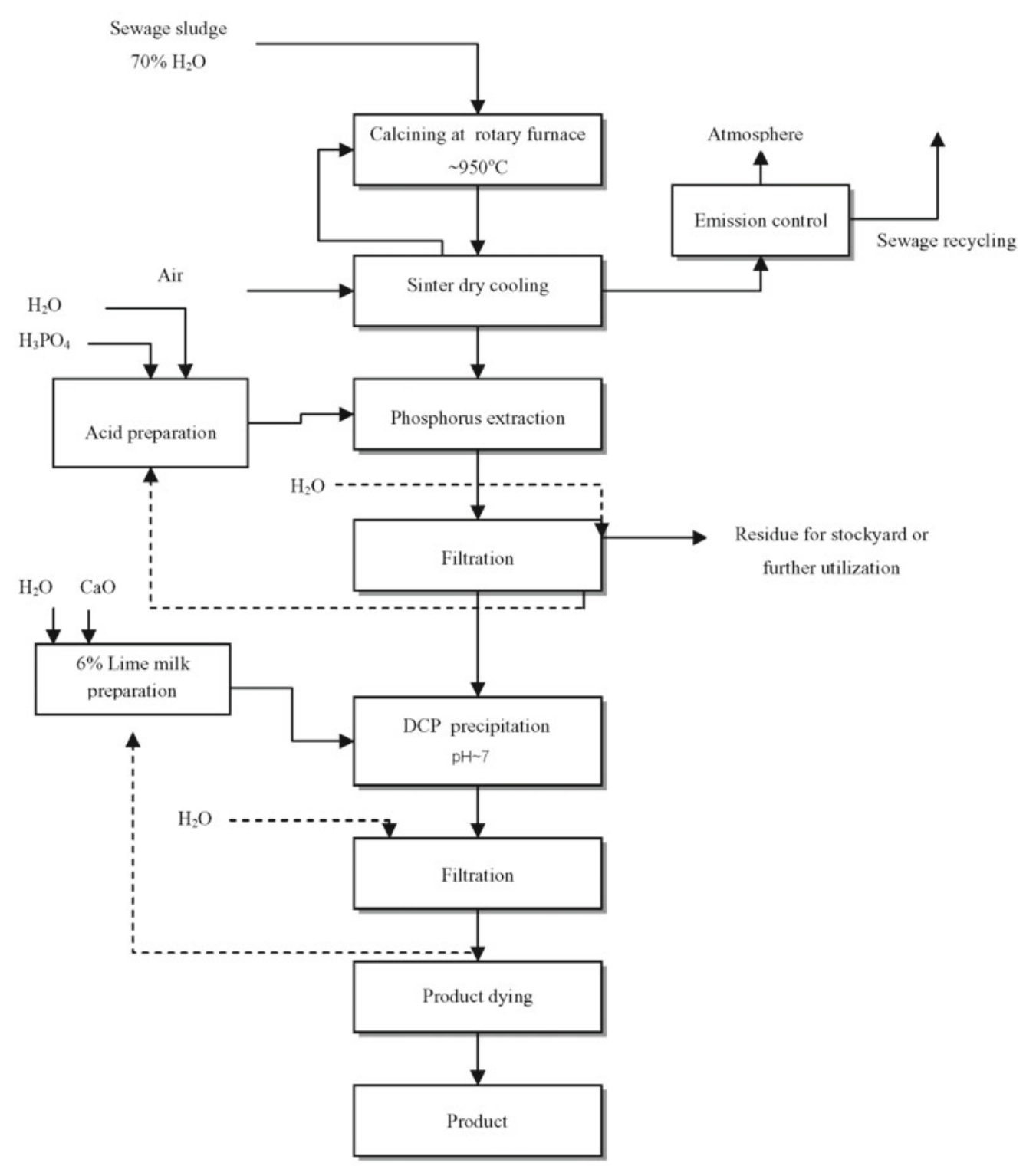

Figure 2. The flow sheet of proposed phosphorus recovery process from sewage sludge

\section{CONCLUSIONS}

On the basis of the conducted research the following conclusions were drawn:

- The selective extraction of phosphorus compounds from ash calcined at $\left(600-1000^{\circ} \mathrm{C}\right)$ was possible because of insoluble hematite phase formation $\left(\mathrm{Fe}_{2} \mathrm{O}_{3}\right)$. The best condition for sewage sludge combustion temperature was determined to be $950^{\circ} \mathrm{C}$.
- Using nitric and phosphoric acid as extraction agents for ash leaching is possible. In the case of nitric acid, application of $0.45 \mathrm{~g} / \mathrm{g}$ acid to ash mass ratio and acid concentration $2.71 \mathrm{~mol} / \mathrm{dm}^{3}$ resulting in $94.89 \%$ of $\mathrm{PO}_{4}^{3-}$ ions recovery and high extraction productivity $-0.423 \mathrm{~mol} \mathrm{PO}_{4}^{3-} / \mathrm{mol} \mathrm{HNO}_{3}$ was found as a favourable condition. As the best conditions for the extraction process with the use of phosphoric acids $0.49 \mathrm{~g} / \mathrm{g}$ ashes 
to acid mass ratio were determined. In those conditions $\mathrm{PO}_{4}{ }^{3-}$ extraction degree $(\alpha)$ reaches $92.09 \%$, and one mole of used acid extracts 0.354 moles of phosphate ions with good mixing conditions. Moreover, the phosphate compounds precipitation does not appear despite the high total phosphate ions concentrations in solution near $457 \mathrm{~g} / \mathrm{dm}^{3}$.

- The best conditions for $\mathrm{CaHPO}_{4} \cdot 2 \mathrm{H}_{2} \mathrm{O}$ precipitation were obtained when extracts after ash leaching with $2.68 \mathrm{~mol} / \mathrm{dm}^{3}$ phosphoric acid are used. The precipitation process should be conducted to complete solution neutralization with $6 \%$ lime milk. The obtained product is characterized by high purity and phosphorus availability compatible with the feed phosphate standard.

\section{ACKNOWLEDGEMENT}

This study was supported in part by the research grant KBN 4 T09B 06824 and protected by polish patents: no. 210459 and 207630 .

\section{LITERATURE CITED}

1. Morse, G.K., Lester, J.N. \& Perry, R. (1993). The economic and environmental impact of phosphorus removal from wastewater in the European Community. Selpher Publications, London.

2. Jasinski, S.M. (2010). U.S. Geological Survey, Mineral Commodity Summaries, chapter Phosphate Rock. United States Government Printing Office, Washington.

3. Schröder, J.J., Cordell, D., Smit, A.L. \& Rosemarin, A. (2009). Sustainable use of phosphorus, European Union tender project ENV.B.1/ETU/2009/0025. Report 357. Plant Research International, Wageningen University and Research Centre, Wageningen, The Netherlands. Retrieved March 23, 2011, from: http://ec.europa.eu/environment/natres/phosphorus.htm.

4. Steen, I. (1998). Phosphorus availability in the 21st century: Management of a non-renewable resources. Phosphorus and Potassium, 217, 25-31.

5. Schröder, J.J., Smit, A.L., Cordell, D. \& Rosemarin, A. (2011). Improved phosphorus use efficiency in agriculture: A key requirement for its sustainable use. Chemosphere, 84, 822-831. DOI:10.1016/j.chemosphere.2011.01.065.

6. Smith, V. (1999). Eutrophication: impacts of excess nutrients of freshwater, marine and terrestrial ecosystems. Environ. Pollut., 100, 179-196.

7. Andersen, A. (2003). Disposal and recycling routes for sewage sludge- report for the UE Commission - DG - Environment - B/2, SEDES. CEEP Scope Newsl., 50, 2-3. Retrieved 12 September, 2010, from: http://www.ceep-phosphates.org/Files/ Newsletter/scope50.pdf.

8. Kowalski, Z., Przewrocki, P., Kulczycka, J., Wzorek, Z., Gorazda, K. \& Jodko, M. (2004). Risk Analysis of Sewage Sludge - Poland and EU Comparative Approach. Pol. J. Environ. Stud., 13(2), 237-244.

9. Dulley, B., (2001). Recycling phosphorus by recovery from sewage. In: Conference Summary - Second International Conference on the recovery of phosphorus from sewage and animal wastes, 12-13 March 2011, Noordwijkerhout, Netherlands.

10. Lundin, M., Olofsson, M., Pettersson, G.J. \& Zetterlund, H. (2004). Environmental and economic assessment of sewage sludge handling options. Resour. Conserv. Recyc., 41(4), 255-278. DOI:10.1016/j.resconrec.2003.10.006.

11. Stark, K., Plaza, E. \& Hultman, B. (2006). Phosphorus release from ash, dried sludge and sludge residue from supercritical water oxidation by acid or base. Chemosphere, 62 (5), 827-832. DOI:10.1016/j.chemosphere.2005.04.069.
12. Rittmann, B.E., Mayer, B., Westerhoff, P. \& Mark Edwards, M. (2011). Capturing the lost phosphorus. Chemosphere, 84, 846-853. DOI:10.1016/j.chemosphere.2011.02.001.

13. Takahashi, M., Kato, S., Shima, H., Sarai, E., Ichioka, T., Hatykawa, S. \& Miyajiri, H. (2001). Technology for recovering phosphorus from incinerated wastewater treatment sludge. Chemosphere, 44, 23-29.

14. Stasta, P., Boran, J., Bebar, L., Stehlik, P. \& Oral, J. (2006). Thermal processing of sewage sludge. Appl. Therm. Eng., 26(13), 1420-1426. DOI:10.1016/j.applthermaleng.2005.05.030.

15. Jozuka, T. (2001). P-recovery from sewage sludge incineration ash. CEEP Scope Newsl., 43, 7-8. Retrieved 11 September, 2010, from: http://www.ceep-phosphates.org/Files/ Newsletter/scope43.pdf.

16. Suzuki, Y. (2003). P-recovery from sewage-sludge incineration ash. CEEP Scope Newsl., 52, 4-5. Retrieved 22 September, 2011, from: http://www.ceep-phosphates.org/Files/ Newsletter/Scope52.pdf.

17. Nakahara, K. \& Hoshino, Y. (2000). US Patent No.6022514. Washington, D.C.: US Patents and Trademarks Office.

18. Vogel, C., Adam, C., Peplinski, B. \& Wellendorf, S. (2010). Chemical reactions during the preparation of $P$ and NPK fertilizers from thermochemically treated sewage sludge ashes. Soil Sci. Plant Nutr, 56(4), 627-635. DOI:10.1111/j.1747-0765.2010.00485.x.

19. Adam, C. , Peplinski, B. , Michaelis, M. , Kley, G. \& Simon, F. (2009). Thermochemical treatment of sewage sludge ashes for phosphorus recovery. Waste Manage. 29(3), 1122-1128. DOI: 10.1016/j.wasman.2008.09.011.

20. Mattenberger, H., Fraissler, G., Brunner, T., Herk, P., Hermann, L. \& Obernberger, I. (2008). Sewage sludge ash to phosphorus fertilizer: Variables influencing heavy metal removal during thermochemical treatment. Waste Manage., 28 (12), 2709-2722. DOI: 10.1016/j.wasman.2008.01.005.

21. Mattenberger, H., Fraissler, G., Jöller, M., Brunner, T., Obernberger, I., Herk, P. \& Hermann, L. (2010). Sewage sludge ash to phosphorus fertilizer (II): Influences of ash and granulate type on heavy metal removal. Waste Manage., 30 (8-9), 1622-1633. DOI: 10.1016/j.wasman.2010.03.037.

22. Nowak, B., Perutka, L., Aschenbrenner, P., Kraus, P., Rechberger, H. \& Winter, F. (2011). Limitations for heavy metal release during thermo-chemical treatment of sewage sludge ash. Waste Manage., 31 (6), 1285-1291. DOI: 10.1016/j. wasman.2011.01.029.

23. Donatello, S., Tong, D. \& Cheeseman, C.R. (2010). Production of technical grade phosphoric acid from incinerator sewage sludge ash (ISSA). Waste Manage., 30 (8-9), 1634-1642. DOI: 10.1016/j.wasman.2010.04.009.

24. Franz, M. (2008). Phosphate fertilizer from sewage sludge ash (SSA). Waste Manage., 28(10), 1809-1818. DOI: 10.1016/j. wasman.2007.08.011.

25. Gorazda, K., Kowalski, Z., Wzorek, Z., Jodko, M., Rzepecki, T., Kulczycka, J., Przewrocki, P. (2003). Possibilities of Phosphorus Recovering from Municipal Sewage and Sewage Sludge. Pol. J. Appl. Chem., 2, 51-63.

26. Gorazda, K. (2004). Research on phosphorus recovery from sewage sludge formed after simultaneous municipal sewage treatment with the use of iron sulfate, as a phosphorus compounds precipitating agent. Unpublished doctoral dissertation, Cracow University of Technology, Cracow, Poland.

27. Gorazda, K., Wzorek, Z. \& Jodko, M. (2005). Phosphorus compounds extraction from the ash after sewage sludge combustion. Pol. J. Chem. Technol., 7(1), 24-28.

28. Gorazda, K. \& Wzorek, Z. (2006). Selection of leaching agent for phosphorus compounds extraction from the sewage sludge ash. Pol. J. Chem. Technol., 8(3), 15-18.

29. Gorazda, K., Wzorek, Z. \& Jodko, M. (2007). The influence of the thermal processing of sewage sludge on the usage properties of the formed ash. Pol. J. Chem. Technol., 9(4), 21-27. DOI: 10.2478/v10026-007-0083-y. 